\title{
Use of commercial probiotics for the improvement of water quality and rotifer density in outdoor mass culture tanks
}

\author{
JAYASREE LOKA, S. M. SONALI, PURBALI SAHA, K. DEVARAJ AND K. K. PHILIPOSE \\ Karwar Research Centre of ICAR-Central Marine Fisheries Research Institute, Karwar, North Kanara - 581301 \\ Karnataka, India \\ e-mail:lokasree@gmail.com
}

\begin{abstract}
An experimental study was carried out to evaluate the efficacy of three commercially available probiotics P1, P2 and P3 consisting of mainly Bacillus spp. and nitrifying bacteria against Vibrio loads in mass culture tanks of the rotifer Brachionus plicatilis. Triplicate tanks were maintained for each of the probiotic treatment as well as for control group. All the tanks were inoculated with 50 rotifers $\mathrm{ml}^{-1}$ and were fed with Nannochloropsis oculata at a density of $1 \times 10^{7}$ cells ml-1. Every alternate day, all the experimental tanks were treated with probiotics at a concentration of $1 \times 10^{4} \mathrm{cfu} \mathrm{m}^{-1}$ and the experiment was carried out for one week. The study showed a significant increase in rotifer density $(p<0.05)$ in all the tanks treated with the probiotics and a maximum density of 400 nos. $\mathrm{ml}^{-1}$ was observed in the tanks treated with P3. After $5^{\text {th }}$ and $6^{\text {th }}$ day of culture, total elimination of Vibrios was also recorded in the tanks treated with P3 and P2 respectively. The study revealed that P3, with a combination of Bacillus, Thiobacillus, Acetobacter and Paracoccus supplemented with enzymes, was found to be most effective in the enhancement of rotifer density and also in the elimination of Vibrios in rotifer mass culture tanks.
\end{abstract}

Keywords: Brachionus plicatilis, Commercial probiotics, Rotifer density, Vibrio

Brachionus plicatilis is the most commonly used live feed as a first feed organism for larval rearing in marine finfish hatcheries. Many studies were carried out on the mass culture of rotifers with different microalgal diets and at different temperatures and salinity conditions (Fielder et al., 2000; Hotos, 2002, 2003; Savas and Guclu, 2006; Kostopoulou and Vadstein, 2007; Jabeur et al., 2013; Abou-Shanab et al., 2016) in the rotifer tanks. Several researchers reported variations in rotifer density due to Vibrio infections which is a major constraint for high density production of rotifers (Skjermo and Vadstein, 1993; Verdonck et al., 1994, 1997; Gomez-Gil et al., 2000; Rombaut et al., 2001; Prol-Garcia et al., 2010, Jayasree et al., 2016). Use of antibiotics in culture systems will lead to the development of antibiotic resistant strains of pathogenic bacteria and will also hinder the growth of cultured organisms. Use of probiotics has been proved to be the best alternative to antibiotic application in aquaculture systems (Gomez-Gill et al., 2000; Planas et al., 2004; Vine et al., 2006; Merrifield et al., 2010). Although there are many reports on the antagonistic activity of Lactobacillus spp. and Bacillus spp. against pathogenic Vibrio spp. (Gatesoupe, 1994, 1999; Vadstein, 1997; Ringo and Birkbeck, 1999; Murillo and Villamil, 2011), very few studies investigated the effect of application of commercially available probiotics on production of live feed (Douillet, 2000; Benetti et al., 2008; Rotman et al., 2011).
The present study was carried out to investigate the efficacy of three commercially available probiotics as antagonistic to Vibrio infections and also on their efficacy in enhancement of rotifer density in outdoor mass culture of $B$. plicatilis. The study was carried out at the marine hatchery complex, Karwar Research Centre of ICAR-Central Marine Fisheries Research Institute, Karwar.

Three commercially available probiotics designated as P1, P2 and P3 (Source: NEOSPARK Drugs and Chemicals Private Limited, India) were selected for the study. All the three probiotics used for the experiment were having a combination of several bacterial strains with major contribution of Bacillus spp. and nitrifying bacteria Table 1. The control group (C) was maintained without addition of any probiotic. All the treatment and control groups were triplicated.

The experimental tanks ( $1 \mathrm{t}$ circular tanks) were disinfected with chlorine for $12 \mathrm{~h}$ and were then filled with 501 of the microalga Nannochloropsis oculata at a concentration of $1 \times 10^{7}$ cells $\mathrm{ml}^{-1}$. Probiotic inocula were prepared by dissolving $10 \mathrm{mg}$ of each probiotic in 1001 of seawater and mixed thoroughly for $30 \mathrm{~min}$. Further dilutions were made to get a final concentration of $1 \times 10^{4} \mathrm{cfu} \mathrm{ml} \mathrm{m}^{-1}$. Three days before the initiation of the experiment, all the experimental tanks other than the 
Table 1. Details of the commercial probiotics used for rotifer culture experiment

\begin{tabular}{|c|c|c|c|}
\hline Code & Product & Bacterial strains & Concentration $\left(\mathrm{cfu} \mathrm{g}^{-1}\right)$ \\
\hline P1 & BioClear & $\begin{array}{l}\text { Bacillus sp., Nitrosomonas sp., Nitrobacter sp., Cellulomonas sp., Acetobacter sp. } \\
\text { (impregnated on granular Zeolite) }\end{array}$ & 3 billion \\
\hline P2 & BioRemid-Aqua & $\begin{array}{l}\text { Bacillus sp., Nitrosomonas sp., Nitrobacter sp., Aerobacter sp., Cellulomonas sp. and } \\
\text { biochemical accelerators with high enzyme activity of lipase, hemicellulase, lactase, proteases } \\
\text { and amylase }\end{array}$ & 184 billion \\
\hline P 3 & QBac & $\begin{array}{l}\text { Bacillus subtilis, Bacillus megaterium, Bacillus licheniformis, Bacillus polymyxa, Bacillus } \\
\text { pumilus, Thiobacillus denitrificans, Paracoccus denitrificans, Acetobacter and } \\
\text { Enzymes protease, amylase, cellulase, hemicellulase and lipase }\end{array}$ & 180 billion \\
\hline
\end{tabular}

control were treated with probiotics at a concentration of $1 \times 10^{4} \mathrm{cfu} \mathrm{m}^{-1}$. On the $3^{\text {rd }}$ day, rotifers (B. plicatilis) were inoculated in the experimental tanks at an initial density of 50 nos. $\mathrm{ml}^{-1}$. Rotifers in all the tanks were fed daily with 51 of $N$. oculata at $1.0 \times 10^{7}$ cells $\mathrm{ml}^{-1}$. On every alternate day, all the experimental tanks were treated with uniform concentration of probiotics $\left(1 \times 10^{4} \mathrm{cfu} \mathrm{ml}^{-1}\right)$ before feeding with $N$. oculata. The experiment was carried out for 7 days, with continuous aeration and with no water exchange during the experimental period.

Rotifer density was determined every day during the experimental period by taking $10 \mathrm{ml}$ of sample from each tank, subsequently five $1 \mathrm{ml}$ subsamples were prepared and counted under microscope. Water quality parameters viz., temperature, salinity, dissolved oxygen (DO), $\mathrm{pH}$ and ammonia levels in the experimental tanks were analysed during the experimental period following standard protocols (APHA, 2004). Total bacterial (Zobell marine agar) and Vibrio loads (Thiosulphate citrate bile salt sucrose agar) were estimated as per standard methods (APHA, 2004). Triplicates were made for each sample and mean values of the replicates were analysed statistically by using two-way analysis of variance (ANOVA).

Results of the study revealed that the rotifer density was significantly higher $(\mathrm{p}<0.05)$ in $\mathrm{P} 3$ treated tanks on termination of the experiment. P3 was found to be the most effective probiotic, with a maximum rotifer density of 400 numbers $\mathrm{ml}^{-1}$. On $7^{\text {th }}$ day of culture, the rotifer density remained almost similar in other tanks treated with $\mathrm{P} 1$ and P2, with rotifer densities of 295 and 288 nos. $\mathrm{ml}^{-1}$ respectively and the mean density in the control tanks was significantly low (95 nos. $\mathrm{ml}^{-1}$ ) (Fig. 1). In control tanks, the density increased gradually reaching a maximum of 150 nos. $\mathrm{ml}^{-1}$ on $3^{\text {rd }}$ day and then started decreasing from $4^{\text {th }}$ day onwards (Fig. 1). The rotifer density in all the treated tanks increased gradually throughout the culture period. The tanks treated with three different probiotics exhibited significant variations in the rotifer densities $(\mathrm{p}<0.05)$. Rotifer density on $1^{\text {st }}$ day of the culture was very low in P1 and P2 treated tanks, whereas, a significant increase was observed in P3 treated tanks.

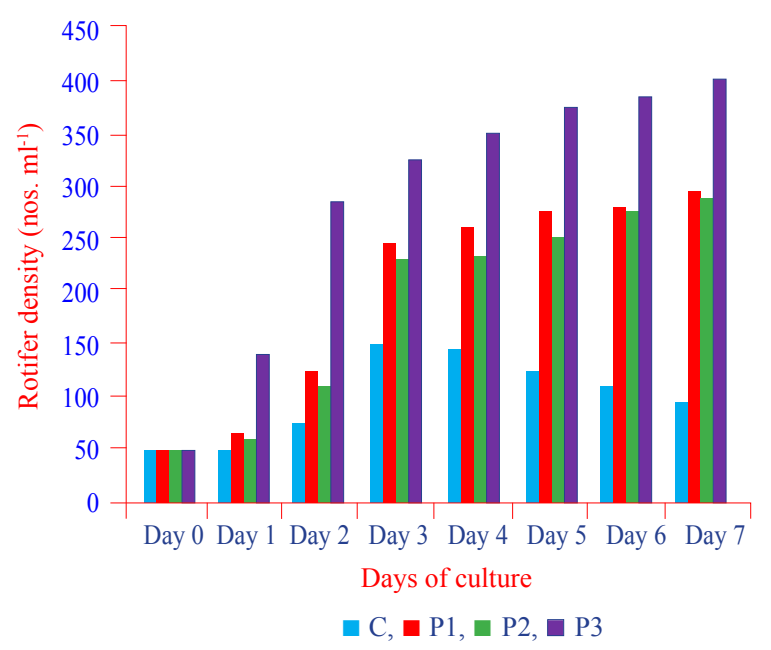

Fig. 1. Density of rotifers fed with $N$. oculata supplemented with three different commercial probiotics

Total bacterial counts in all the treatments increased continuously from $2^{\text {nd }}$ day onwards, till the completion of the experiment. Total bacterial loads of control tanks ranged between $0.19 \times 10^{4}$ to $0.39 \times 10^{4} \mathrm{cfu} \mathrm{ml}^{-1}$, whereas, the bacterial loads in probiotic treated tanks were found significantly high with a maximum of $0.21 \times 10^{5} \mathrm{cfu} \mathrm{m}^{-1}$ in P3 treated tank. Total bacterial loads of water in P1, P2 and $\mathrm{P} 3$ treated tanks varied between $0.33 \times 10^{4}$ to $0.15 \mathrm{x}$ $10^{5} \mathrm{cfu} \mathrm{ml}^{-1}, 0.39 \times 10^{4}$ to $0.16 \times 10^{5} \mathrm{cfu} \mathrm{ml}^{-1}$ and $0.34 \times 10^{4}$ to $0.21 \times 10^{5} \mathrm{cfu} \mathrm{ml}^{-1}$ respectively (Fig. 2). From $2^{\text {nd }}$ day onwards, significantly higher total bacterial loads were recorded in all the probiotic treated tanks compared to control tanks.

It was observed that probiotics played a significant role in controlling Vibrios in rotifer culture tanks. Vibrio loads of water in control tank ranged from $0.25 \times 10^{2}$ to $0.26 \times 10^{3} \mathrm{cfu} \mathrm{ml}^{-1}$ (Fig. 3). In probiotic treated tanks, the Vibrio loads reduced significantly with the days of culture. A significant variation between the three probiotic treatments and also between the days of culture $(p<0.05)$ was observed. Out of the three probiotic treatments, P3 was found more effective in reducing the Vibrio loads and it completely eliminated the Vibrios from $5^{\text {th }}$ day onwards. In P1 treated tanks, Vibrio loads started decreasing from 


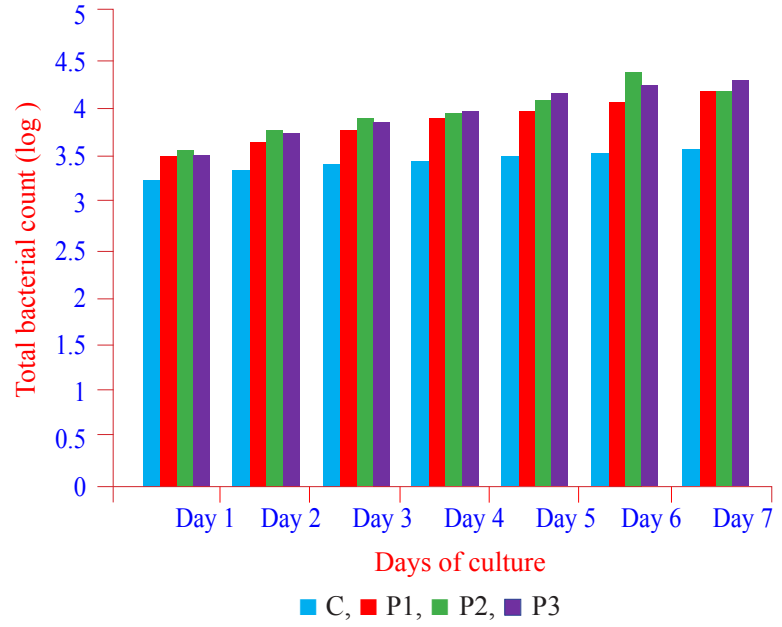

Fig. 2. Total bacterial count ( $\mathrm{cfu} \mathrm{m}^{-1}$ ) of water in rotifer tanks treated with three different commercial probiotics

$2^{\text {nd }}$ day onwards. At the end of the experiment, total Vibrio loads in the control and P1 treated tanks were $0.26 \times 10^{3}$ and $0.2 \times 10^{1} \mathrm{cfu} \mathrm{m}^{-1}$ respectively (Fig. 3). However, on termination of the experiment, P2 and P3 treated tanks recorded zero Vibrio loads. Vibrio loads of P1 and P2 in the initial two days were almost similar but later, loads gradually reduced and found to be zero in P2 treated tanks. Complete elimination of Vibrios in P2 and P3 treated tanks was recorded on $6^{\text {th }}$ and $5^{\text {th }}$ day of culture respectively (Fig. 3). Complete elimination of the Vibrios was not observed in P1 treated tanks.

The water quality parameters recorded in the experimental tanks are given in Table 2. No significant difference was recorded in water temperature and salinity, between the treatments $(\mathrm{p}>0.05)$. But ammonia levels showed significant variation between treatments $(p<0.05)$. A clear positive correlation was observed between the

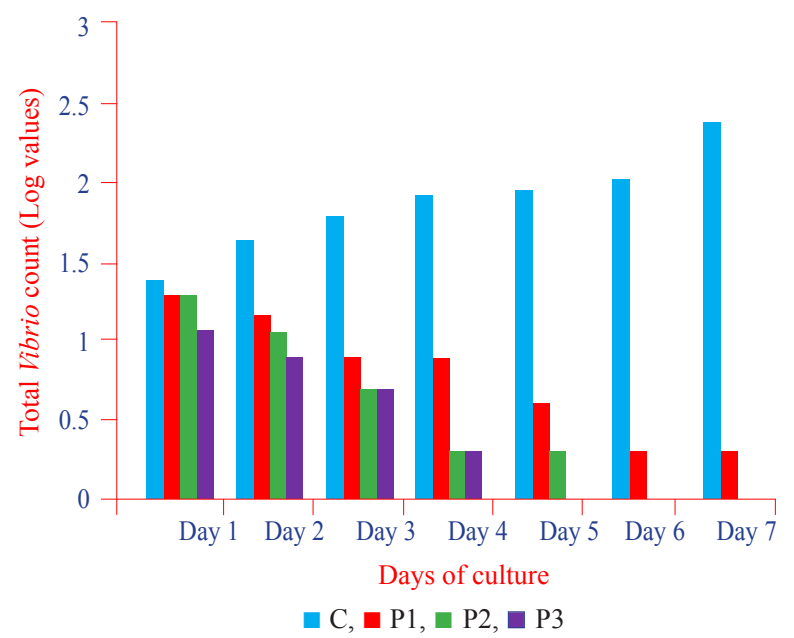

Fig. 3. Total Vibrio count $\left(\mathrm{cfu} \mathrm{ml}^{-1}\right)$ of water in rotifer tanks treated with three different commercial probiotics ammonia levels and occurrence of Vibrios in water of rotifer culture tanks in the different treatment groups (with $\mathrm{r}$ values of $0.89,0.4,0.88$ and 0.79 for $\mathrm{C}, \mathrm{P} 1, \mathrm{P} 2$ and $\mathrm{P} 3$ respectively). Higher Vibrio loads were recorded with increase of ammonia levels.

Results of the present study revealed significant influence of probiotic treatment on the rotifer density and also on the elimination of Vibrio loads of water in the culture tanks. Bacillus strains are the most suitable probiotics for aquaculture owing to their availability in all the environments and also in the gut of aquatic organisms (Hong et al., 2005). Rotifer density was found enhanced with application of the probiotics in all the treatments, with a maximum of 400 nos. $\mathrm{ml}^{-1}$ in P3 treated tanks. Significantly $(\mathrm{p}<0.05)$ lower rotifer density was noticed in control tanks ( 95 nos. $\mathrm{ml}^{-1}$ ) as compared to probiotic treated tanks on $7^{\text {th }}$ day of culture. Zink et al. (2013) reported significantly high population density in probiotic treated rotifer batch cultures. Yu and Hirayama (1986) stated that Bacillus spp. could reduce production of pathogenic bacteria and improve rotifer population growth.

Murillo and Villamil (2011) recorded decrease in heterotrophic bacterial levels in rotifer cultures when supplemented with Bacillus strains. They found significant decrease in Vibrio levels after 3 and 6 days of treatment with $B$. subtilis. Our results also recorded a decreasing trend in Vibrio loads in the tanks treated with probiotics and complete elimination of Vibrios was observed from $5^{\text {th }}$ day onwards in P3 treated tanks. The inhibition of harmful pathogenic bacteria with the application of probiotics could be due to the enzymes released by probiotic bacteria which might help to improve digestion in rotifers (Murillo and Villamil, 2011). Probiotic inclusion was found effective in the manipulation of bacterial communities in rotifer cultures (Zink et al., 2013). The total bacterial loads of water were found high in all the treatments during the present investigation, but the Vibrio loads were found to decrease in probiotic treated rotifer tanks with complete elimination of Vibrios observed from $5^{\text {th }}$ day of culture in $\mathrm{P} 3$ treated tanks.

The water quality parameters recorded in the present study were all within the limits but showed variations with days of culture and between the treatments $(p<0.05)$. Ammonia ( $\mathrm{mg} \mathrm{l}^{-1}$ ) levels were found to show impact on the occurrence of Vibrio loads in rotifer culture tanks. A strong positive correlation between ammonia levels and total Vibrio loads was recorded during the present experiment. Earlier reports also stated that Bacillus spp. reduces ammonia to levels that inhibit rotifer population 
Table 2. Water quality parameters (Mean $\pm \mathrm{SD}$ ) recorded in experimental rotifer tanks

\begin{tabular}{|c|c|c|c|c|c|}
\hline Days of culture & Treatment & Temperature $\left({ }^{\circ} \mathrm{C}\right)$ & Salinity (ppt) & $\mathrm{pH}$ & Ammonia $\left(\mathrm{mg}^{-1}\right)$ \\
\hline \multirow[t]{4}{*}{0} & $\mathrm{C}$ & $28.5 \pm 0.02$ & $25 \pm 0$ & $7.8 \pm 0.01$ & $0.01 \pm 0.002$ \\
\hline & P1 & $28.6 \pm 0.01$ & $25 \pm 1$ & $7.8 \pm 0.02$ & $0.01 \pm 0.001$ \\
\hline & P2 & $28.5 \pm 0.05$ & $25 \pm 0$ & $7.8 \pm 0.02$ & $0.01 \pm 0.0005$ \\
\hline & P3 & $28.5 \pm 0.02$ & $25 \pm 0$ & $7.8 \pm 0.02$ & $0.01 \pm 0.001$ \\
\hline \multirow[t]{4}{*}{1} & $\mathrm{C}$ & $28.5 \pm 0.05$ & $25 \pm 1$ & $7.8 \pm 0.01$ & $0.02 \pm 0.006$ \\
\hline & P1 & $28.5 \pm 0.1$ & $25 \pm 1$ & $7.8 \pm 0.02$ & $0.02 \pm 0.005$ \\
\hline & $\mathrm{P} 2$ & $28.6 \pm 0.05$ & $25 \pm 1$ & $7.8 \pm 0.02$ & $0.02 \pm 0.001$ \\
\hline & P3 & $28.6 \pm 0.05$ & $25 \pm 1$ & $7.8 \pm 0.02$ & $0.01 \pm 0.001$ \\
\hline \multirow[t]{4}{*}{2} & $\mathrm{C}$ & $29.1 \pm 0.2$ & $26 \pm 0$ & $7.9 \pm 0.01$ & $0.02 \pm 0.0025$ \\
\hline & P1 & $29.3 \pm 0.05$ & $26 \pm 1$ & $7.9 \pm 0.05$ & $0.02 \pm 0.0028$ \\
\hline & $\mathrm{P} 2$ & $29.2 \pm 0.4$ & $26 \pm 0$ & $7.9 \pm 0.05$ & $0.01 \pm 0.0005$ \\
\hline & P3 & $29.1 \pm 0.05$ & $26 \pm 1$ & $7.9 \pm 0.02$ & $0.01 \pm 0.008$ \\
\hline \multirow[t]{4}{*}{3} & $\mathrm{C}$ & $28.8 \pm 0.05$ & $26 \pm 0$ & $7.8 \pm 0.02$ & $0.04 \pm 0.005$ \\
\hline & P1 & $28.7 \pm 0.1$ & $26 \pm 1$ & $7.9 \pm 0.01$ & $0.04 \pm 0.005$ \\
\hline & P2 & $28.7 \pm 0.05$ & $26 \pm 0$ & $7.8 \pm 0.01$ & $0.01 \pm 0.002$ \\
\hline & P3 & $28.8 \pm 0.05$ & $26 \pm 1$ & $7.9 \pm 0.02$ & $0.02 \pm 0.002$ \\
\hline \multirow[t]{4}{*}{4} & $\mathrm{C}$ & $29.2 \pm 0.2$ & $26 \pm 1$ & $7.8 \pm 0.02$ & $0.04 \pm 0.002$ \\
\hline & P1 & $29.1 \pm 0.05$ & $26 \pm 1$ & $7.8 \pm 0.04$ & $0.02 \pm 0.002$ \\
\hline & P2 & $29.1 \pm 0.2$ & $26 \pm 0$ & $7.8 \pm 0.02$ & $0.01 \pm 0.006$ \\
\hline & P3 & $29.2 \pm 0.05$ & $26 \pm 1$ & $7.8 \pm 0.05$ & $0.01 \pm 0.006$ \\
\hline \multirow[t]{4}{*}{5} & $\mathrm{C}$ & $28.9 \pm 0.2$ & $26 \pm 1$ & $7.8 \pm 0.03$ & $0.06 \pm 0.008$ \\
\hline & P1 & $28.8 \pm 0.1$ & $26 \pm 1$ & $7.8 \pm 0.05$ & $0.03 \pm 0.004$ \\
\hline & P2 & $28.8 \pm 0.05$ & $26 \pm 1$ & $7.8 \pm 0.04$ & $0.01 \pm 0.001$ \\
\hline & P3 & $28.9 \pm 0.1$ & $26 \pm 1$ & $7.8 \pm 0.04$ & 0 \\
\hline \multirow[t]{4}{*}{6} & $\mathrm{C}$ & $29.2 \pm 0.1$ & $26 \pm 1$ & $7.8 \pm 0.04$ & $0.08 \pm 0.002$ \\
\hline & P1 & $29.3 \pm 0.05$ & $26 \pm 0$ & $7.8 \pm 0.01$ & $0.01 \pm 0.001$ \\
\hline & P2 & $29.2 \pm 0.06$ & $26 \pm 0$ & $7.8 \pm 0.01$ & 0 \\
\hline & P3 & $29.3 \pm 0.05$ & $26 \pm 0$ & $7.8 \pm 0.01$ & 0 \\
\hline \multirow[t]{4}{*}{7} & $\mathrm{C}$ & $29.2 \pm 0.05$ & $26 \pm 0$ & $7.9 \pm 0.02$ & $0.08 \pm 0.005$ \\
\hline & P1 & $29.1 \pm 0.1$ & $26 \pm 0$ & $7.9 \pm 0.008$ & $0.02 \pm 0.004$ \\
\hline & P2 & $29.1 \pm 0.2$ & $26 \pm 0$ & $7.9 \pm 0.01$ & 0 \\
\hline & P3 & $29.1 \pm 0.05$ & $26 \pm 0$ & $7.9 \pm 0.01$ & 0 \\
\hline
\end{tabular}

(Schulter and Groeneweg, 1985; Chen and Chen, 2001). Zink et al. (2013) reported significant decrease in DO levels in probiotic treated tanks owing to higher rotifer populations. The high bacterial loads and ammonia levels were the major factors contributing to reduction in the density of rotifers in control tanks. Total bacterial loads in treatment tanks were high in water due to additional bacterial inocula from probiotic bacterial supplementation, which might have led to elimination of Vibrio spp. from probiotic treated tanks.

Results of the present study, clearly indicate that application of probiotic bacteria could be used as an alternative for antibiotic treatment in elimination of Vibrios and also for enhancement of rotifer density in outdoor mass culture systems. However, further studies are needed to characterise the compounds that are responsible for the antagonistic activity of these probiotics against vibrios

\section{Acknowledgements}

Authors are thankful to the Director, ICAR-Central Marine Fisheries Research Institute, Kochi for providing facilities to carry out this work.

\section{References}

Abou-Shanab, R. A. I., Manjinder, S., Anangelica, R. C., Grace, P., Thomas, B. M. and Keshav, D. 2016. Effect of Brachionus rubens on the growth characteristics of various species of microalgae. Electronic J. Biotech., 22: 68-74.

APHA 2004. Standard methods for the examination of water and waste water, $15^{\text {th }}$ edn. American Public Health Association, Washington DC, 1134 pp.

Benetti, D. D., Sardenberg, B., Welch, A., Hoenig, R., Orhun, M. R. and Zink, I. 2008. Intensive larval husbandry and fingerling production of cobia Rachycentron canadum. Aquaculture, 281: 22-27. 
Chen, C. C. and Chen, S. N. 2001. Water quality management with Bacillus spp. in the high-density culture of red-parrot fish Cichlasoma citrinellum x C. synspilum. N. Am. J. Aquac., 63: 66-73.

Douillet, P. A. 2000. Bacterial additives that consistently enhance rotifer growth under synxenic culture conditions - Evaluation of commercial products and pure isolates. Aquaculture, 182: 249-260.

Fielder, D. S., Purser, G. J. and Battaglene, S. C. 2000. Effect of rapid change in temperature and salinity on availability of the rotifers Brachionus rotundiformis and Brachionus plicatilis. Aquaculture, 189: 85-99.

Gatesoupe, F. J. 1994. Lactic acid bacteria increase the resistance of turbot larvae, Scophthalmus maximus (L.) against pathogenic Vibrio. Aquat. Liv. Res., 7: 277-282.

Gatesoupe, F. J. 1999. The use of probiotics in aquaculture. Aquaculture, 180: 147-165.

Gomez-Gil, B., Roque, A. and Turnbull, J. F. 2000. The use and selection of probiotic bacteria for use in the culture of larval aquatic organisms. Aquaculture, 191: 259-270.

Hong, H. A., Duc, L. H. and Cutting, S. M. 2005. The use of bacterial spore formers as probiotics. FEMS Microbiol. Rev., 29: 813-835.

Hotos, G. N. 2002. Selectivity of the rotifer Brachionus plicatilis fed mixtures of algal species with various cell volumes and cell densities. Aquac. Res., 33: 949-957.

Hotos, G. N. 2003. Growth, filtration and ingestion rate of the rotifer Brachionus plicatilis fed with large (Asteromonas gracilis) and small (Chlorella sp.) celled algal species. Aquac. Res., 34: 793-802.

Jabeur, C., Merghni, A. and Kamoun, F. 2013. Feeding rotifers, Brachionus plicatilis with microalgae cultivated in Tunisia. J. Env. Sci. Toxicol. Food Technol., 4(5): 105-112.

Jayasree Loka, Sonali, S. M., Purbali Saha and Philipose, K. K. 2016. Bacterial flora of water and rotifers in outdoor mass culture tanks fed with different microalgal diets. J. Life Sci., 10: 123-127.

Kostopoulou, V. and Vadstein, O. 2007. Growth performance of the rotifers Brachionus plicatilis, B. nevada and B.cayman under different food concentrations. Aquaculture, 273: 449-458.

Merrifield, D. L., Dimitroglou, A., Foey, A., Davies, S. J., Baker, R. T. M., Bogwald, J., Castex, M. and Ringo, E. 2010. The current status and future focus of probiotic and prebiotic applications for salmonids. Aquaculture, 302: 1-18.

Murillo, I. and Villamil, L. 2011. Bacillus cereus and Bacillus subtilis used as probiotics in rotifer (Brachionus plicatilis) cultures. J. Aquac. Res. Develop., S1:007. doi:10.4172/2155-9546.S1-007.
Planas, M., Vazquez, J. A., Marques, J., Perez-Lomba, R., Gonzalez, M. P. and Murado, M. 2004. Enhancement of rotifer (Brachionus plicatilis) growth by using terrestrial lactic acid bacteria. Aquaculture, 240: 313-329.

Prol-Garcia, M. J., Planas, M. and Pintado, J. 2010. Different colonisation and residence time of Listonella anguillarum and Vibrio splendidus in the rotifer, Brachionus plicatilis determined by real-time PCR and DGGE. Aquaculture, 302: 26-35.

Ringo, E. and Birkbeck, T. H. 1999. Intestinal microflora of fish larvae and fry. Aquac. Res., 30: 73-93.

Rombaut, G., Suantika, G., Boon, N., Maertens, S., Dhert, P., Top, E., Sorgeloos, P. and Verstraete, W. 2001. Monitoring of the evolving diversity of the microbial community present in rotifer cultures. Aquaculture, 198: 237-252.

Rotman, F., Riche, M., Van Wyk, P. and Benetti, D. D. 2011. Efficacy of a commercial probiotic relative to oxytetracycline as Gram negative bacterial control agents in a rotifer (Brachionus plicatilis) batch culture. N. Am. J. Aquac., 73: 343-349.

Savas, S. and Guclu, Z. 2006. Filtration and ingestion rates of the rotifer, Brachionus plicatilis fed five species of microalgae at different cell densities. Isr. J. Aquac. Bamidgeh, 58(1): 39-45.

Schulter, M. and Groeneweg, J. 1985. The inhibition by ammonia of population growth of the rotifer, Brachionus rubens, in continuous culture. Aquaculture, 46: 215-220.

Skjermo, J. and Vadstein, O. 1993. Characterisation of the bacterial flora of mass cultivated Brachionus plicatilis. Hydrobiologia, 255-256: 185-191.

Vadstein, O. 1997. The use of immunostimulation in marine larviculture: possibilities and challenges. Aquaculture, 155: 401-417.

Verdonck, L., Grisez, L., Sweetman, E., Minkhoff, G., Sorgeloos, P. and Ollevier, F. J. Swings 1997. Vibrios associated with routine productions of Brachionus plicatilis. Aquaculture, 149: 203-214.

Verdonck, L., Swings, J., Kersters, K., Dehasque, M., Sorgeloos, P. and Leger, P. H. 1994. Variability of the microbial environment of rotifer (Brachionus plicatilis) and Artemia production systems. J. World Aquac. Soc., 25: 55-59.

Vine, N. G., Leukes, W. D. and Kaiser, H. 2006. Probiotics in marine larviculture. FEMS Microbiol. Rev., 30: 404-427.

Yu, J. P. and Hirayama, K. 1986. The effect of un-ionised ammonia on the population growth of the rotifer in mass culture. Bull. Jap. Soc. Sci. Fish., 52: 1509-1513.

Zink, I. C., Douillet, P. A. and Benetti, D. D. 2013. Improvement of rotifer, Brachionus plicatilis population growth dynamics with inclusion of Bacillus spp. probiotics. Aquac. Res., 44: 200-211.

Date of Receipt $\quad$ : 29.07.2016

Date of Acceptance : $\quad 05.12 .2016$ 